\title{
A SENSITIVE KINETIC SPECTROPHOTOMETRIC DETERMINATION OF TRACES OF TUNGSTEN IN SOLUTION BASED ON ITS INHIBITORY EFFECT ON THE DECOLORIZATION REACTION OF POTASSIUM PERMANGANATE
}

\author{
Branka Petkovic $^{1 *}$, Ružica Micić ${ }^{1}$, Ranko Simonović ${ }^{1}$ \\ ${ }^{1}$ Faculty of Natural Sciences and Mathematics, University of Piština, Kosovska Mitrovica, Serbia.
}

\begin{abstract}
The present work describes a rapid and sensitive method for the determination of ultramicro amounts of tungsten (VI) based on its inhibitory effect on the oxidation of 4hidroxycoumarine by potassium permanganate in the presence of hydrochloric acid. The sensitivity of the method is $20 \mathrm{ng} / \mathrm{cm}^{3}$. The probable relative error is $-4.8-13 \%$ for the $W(V I)$ concentration range 250 to $20 \mathrm{ng} / \mathrm{cm}^{3}$, respectively. Kinetic equations for the investigated process which

determine the order of the reactions regarding to each reaction parameter under certain experimental conditions were proposed, and they allowed quantification of the unknown concentrations $W(V I)$ in solution. The detection and quantification limit of the method are 4.5 and $15.1 \mathrm{ng} / \mathrm{cm}^{3}$. The effects of certain foreign ions upon the reaction rate were determined for the assessing the selectivity of the method.
\end{abstract}

Key words: Kinetic method, spectrophotometric determination, inhibition, tungsten(VI), 4-hidroxycoumarine.

\section{INTRODUCTION}

Tungsten is a metal which occurs naturally in the lithosphere, usually in small concentrations and it is also found in oceans and sometimes in other groundwaters in trace amounts (Koutsospyros et al., 2006). This metal is biologically active and it can be found in a number of tungsten-containing enzymes (W-enzymes) (L'vov et al., 2002).

Tungsten usually can be found in the most stable oxidation state VI, but it also occurs in the oxidation states III, IV and V. It has the highest melting/boiling points among elements, a tensile strength at high temperature, resistance to corrosion and a high density and hardness. Because of these unique properties, tungsten has various applications in industry. It is used as a filament in incandescent lamps, as steels in magnetos, springs, contact points, spark plugs, and valves and for other products. (Koutsospyros et al., 2006).

In the past, tungsten was considered as less toxic element due to its insolubility and insufficient knowledge about environmental or toxicological effects (Koutsospyros et al., 2006), (Tajima, 2003). Recently, it has been reported that dissolution of metallic tungsten particles may cause adverse environmental effects such as soil acidification as well as direct and indirect toxic effects in plants, and other living organisms (Strigul a, 2010). Based on these studies, the environmental regulations of tungsten as a "nontoxic" and "environmentally inert" definitely need re-evaluation (Strigul a, 2010), (Strigul b et al., 2010).

It is very difficult to determine tungsten besides the other transition metals, especially in trace levels using chemical methods. It has been determined by different techniques (mostly by spectrophotometric methods (Rohilla et al., 2013), (Masti et al., 2002), ICP-MS (JIS G 1220, 1994), (JIS G 1258, 2000), (Strekopytov et al., 1997) and electrochemical methods (AlvaradoGámez et al., 2015), (Tanaka et al., 2001), (Zarei et al., 2010).

The kinetic spectrophotometric methods are known as sensitive methods for element quantification (Muller et al., 1980). By studding red-ox reactions of permanganate with organic compounds (Petković et al., 2007), (Micić et al., 2006), it is noticed that tungsten has performed inhibitory effect on the oxidation of 4-hidroxycoumarine by $\mathrm{KMnO}_{4}$ in the presence of hydrochloride acid ( $\mathrm{pH}$ 1.2-2). The reaction was recorded spectrophotometrically, based on measuring the decrease in the absorbance of the solution. The aim of this work was to investigate the possibility of sensitive and selective tungsten determination by measuring the rate of change in 
absorbance of reaction system (4-hidroxycoumarine by $\mathrm{KMnO}_{4}$ in the presence of hydrochloride acid and $\mathrm{W}(\mathrm{VI}))$ with time at $525 \mathrm{~nm}$.

\section{EXPERIMENTAL}

\subsection{Apparatus}

The investigated reaction rate was folowed by spectrophotometric method at Perkin-Elemer Lambda 15 spectrophotometer, with thermostated cylindrical cells, length $10 \mathrm{~cm}$. All pH values were measured by the radiometer PHM 29Bb pH-meter and a combined glass-calomel electrode, GK2311C. Before the beginning of the reaction, all solutions were termostated in water-bath. The optimal wavelength of $525 \mathrm{~nm}$, as a higher absorbance maximum of $\mathrm{KMnO}_{4}$, was applied for kinetic measurements.

\subsection{Reagents}

The $\mathrm{KMnO}_{4}$ solution $\left(0.02 \mathrm{~mol} / \mathrm{dm}^{3}\right)$ was prepared from an ampoule produced by „Merck“. The 4hidroxycoumarine $1 \cdot 10^{-3} \mathrm{~mol} / \mathrm{dm}^{3}$ solution was made by direct weighing of the solid substance. The $\mathrm{HCl}$ solution $\left(0.2 \mathrm{~mol} / \mathrm{dm}^{3}\right)$ was prepared from $37 \%$ concentrated $\mathrm{HCl}$ solution. The basic $\mathrm{W}(\mathrm{VI})$ solution $1000 \mathrm{ng} / \mathrm{cm}^{3}$ was prepared by dissolving $1.7942 \mathrm{~g}$ $\mathrm{Na}_{2} \mathrm{WO}_{4} \cdot 2 \mathrm{H}_{2} \mathrm{O}$ (analytical grade) in deionized water with conductivity less than $0.5 \mu \mathrm{S}$. The exact concentration was determined volumetrically. Analytical grade reagents, deionized water and polyethylene vessels were used throughout.

\subsection{Procedure}

Inhibited reaction was followed spectrophotometrically by monitoring the change in absorbance at $525 \mathrm{~nm}$. The initial concentrations of each of the reactants were varied in turn systematically (Muller et al., 1980), (Alekseev, 1973), while the initial concentrations of the other reactants were being kept constant. The same procedure as in previous works (Petković et al., 2007), (Micić et al., 2006) was used in experiments. The selected volumes of the reactants were put into a $20 \mathrm{~cm}^{3}$ standard flask, in order: 4-hidroxycoumarine, $\mathrm{HCl}$, inhibitor and water to make up the exact predetermined volume. The flask was kept in the thermostat for $10 \mathrm{~min}$, and then the solution was filled up with $\mathrm{KMnO}_{4}$ to the mark and vigorously shaken. The cell of the photometer was rinsed well and filled with the solution. The absorbance was measured every $15 \mathrm{~s}$, for 3-6 min the time has been measured at the moment of $\mathrm{KMnO}_{4}$ addition. The initial concentrations of the reagent solutions after dilution to $20 \mathrm{~cm}^{3}$ were: $1 \cdot 10^{-5}-4 \cdot 10^{-5}$ $\mathrm{mol} / \mathrm{dm}^{3}$ 4-hidroxycoumarine, $1.5 \cdot 10^{-5}-4.5 \cdot 10^{-5}$ $\mathrm{mol} / \mathrm{dm}^{3} \mathrm{KMnO}_{4}, 1.0 \cdot 10^{-2}-5.62 \cdot 10^{-2} \mathrm{~mol} / \mathrm{dm}^{3} \mathrm{H}_{3} \mathrm{O}^{+}$ ions; $10-250 \mathrm{ng} / \mathrm{cm}^{3} \mathrm{~W}(\mathrm{VI})$.

\section{RESULTS AND DISCUSSION}

The determination of ultramicro amounts of tungsten(VI) is based on its inhibitory effect on the oxidation of 4-hidroxycoumarine by $\mathrm{KMnO}_{4}$ in the presence of hydrochloric acid in strong acidic solution - $\mathrm{pH}$ less then 2. It is interesting that above the value of $\mathrm{pH}=2, \mathrm{~W}(\mathrm{VI})$ influences catalytically on the same reaction. Catalitic effect of $\mathrm{W}(\mathrm{VI})$ on mention reaction can used for determination of W(VI) in acetate buffer, but selectivity of the method is much lower than in proposed method with inhibitotory effect. On the basis of the results obtained by investigation of the indicatory reaction kinetics for the determination of $\mathrm{W}(\mathrm{VI})$ nanogram amounts, the kinetic method was elaborated for $\mathrm{W}(\mathrm{VI})$ trace determination within the range from 20 to $250 \mathrm{ng} / \mathrm{cm}^{3} \mathrm{~W}(\mathrm{VI})$.

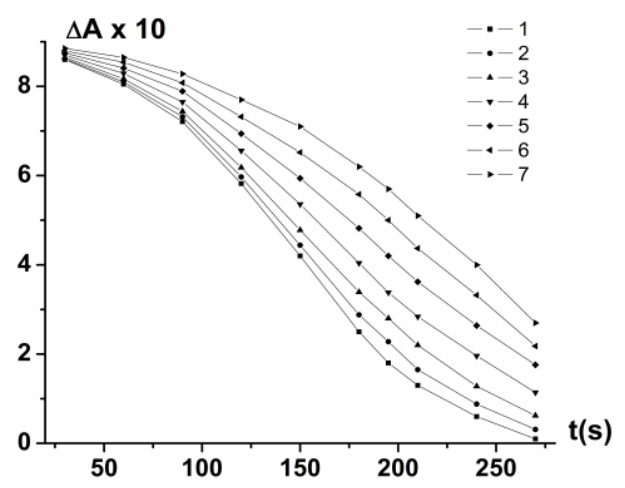

Fig.1. Change of absorbance $(\Delta \mathrm{A})$ for different concentrations W(IV) $\left(\mathrm{ng} / \mathrm{cm}^{3}\right), \quad \mathrm{T}=298 \mathrm{~K}, 1=10$ cm; 1-0.0; 2-20; 3-50; 4-100; 5-150; 6-200; 7$250 ; \mathrm{C}_{\mathrm{KMnO} 4}=3.6 \cdot 10^{-5} ; \mathrm{C}_{4-\mathrm{OHcoum}}=2.75 \cdot 10^{-5} \mathrm{~mol} / \mathrm{dm}^{3}$

Based on the shape of the curves obtained by mesuring absorbance for different concentartions of $\mathrm{W}$ (VI) depending of time (Fig. 1), the differencial time method for processing the kinetic data was selected (Muller et al., 1980). The maximum difference between non-catalytic and catalytic reactions occured at $195 \mathrm{~s}$ and this time is selected as optimal and fixed in further experiments.

\section{Chemistry}




\subsection{Effect of $\mathbf{p H}$}

The effect of $\mathrm{pH}$ on non-inhibited and inhibited reaction rates is shown in Fig. 2. It appears that there is a complex relationship between $\mathrm{pH}$ and the reaction rate, i.e. a reaction order is variable with respect to hydrogen-ion concentration for the range of studied concentrations. For further work, $\mathrm{pH}=1.74$ was selected for quantitative applications.

It is important to notice that $\mathrm{W}(\mathrm{VI})$ could be separated from Mo(VI) (which also shows inhibiting effect on permanganate reaction with coumarine), by monitoring the change in absorbance at $525 \mathrm{~nm}$ on $\mathrm{pH}$ lower than 1.2.

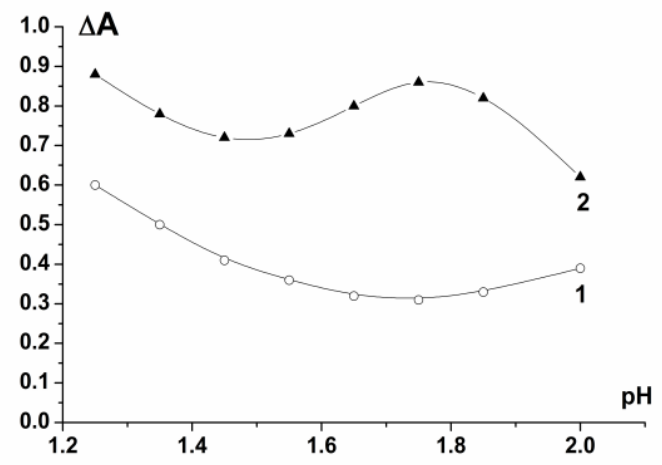

Fig. 2. Dependence of the reaction rate on $\mathrm{pH}$. Initial conditions: $\quad 3.6 \cdot 10^{-5} \quad \mathrm{~mol} / \mathrm{dm}^{3} \quad \mathrm{KMnO}_{4} ; \quad 2.75 \cdot 10^{-5}$ $\mathrm{mol} / \mathrm{dm}^{3}$ 4-hidroxycoumarine; $200 \mathrm{ng} / \mathrm{cm}^{3} \mathrm{~W}(\mathrm{VI})$; temperature $25 \pm 0.1{ }^{\circ} \mathrm{C}$; 1-inhibited reaction; 2-noninhibited reaction.

\subsection{Effect of 4-hydroxyl coumarine concentration}

The dependence of $\Delta$ Aon the 4-hidroxycoumarine concentration is shown in Fig. 3. The maximum difference between the rates of inhibited and noninhibited reactions has been observed for 4hidroxycoumarine concentration of $2.75 \cdot 10^{-5} \mathrm{~mol} / \mathrm{dm}^{3}$. The inhibited reaction is the first-order in the full range of examined concentrations, while the basic noninhibited reaction is the first-order for the concentrations of 4-hidroxycoumarine less than $2.75 \cdot 10^{-5} \mathrm{~mol} / \mathrm{dm}^{3}$.

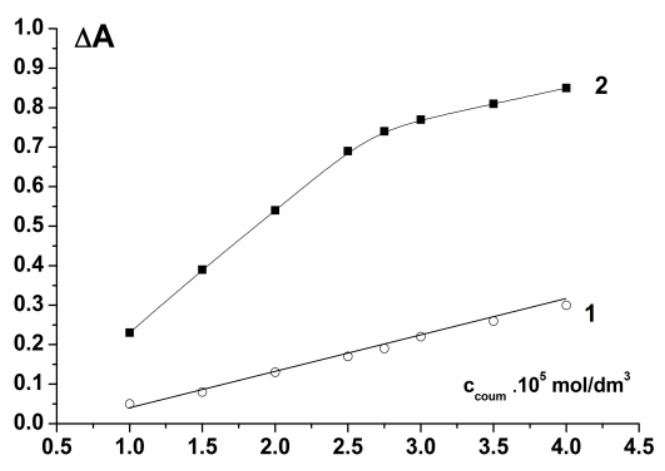

Fig. 3. Dependence of the reaction rate on 4-hidroxycoumarine concentration. Initial conditions: $3.610^{-5} \mathrm{~mol} / \mathrm{dm}^{3} \mathrm{KMnO}_{4} ; \mathrm{pH}=1.74 ; 200 \mathrm{ng} / \mathrm{cm}^{3}$ $\mathrm{W}$ (VI); temperature $25 \pm 0.1{ }^{\circ} \mathrm{C}$; 1-inhibited reaction; 2-non-inhibited reaction

\subsection{Effect of potassium permanganate concentration}

The dependence of the reaction rates on the concentration of $\mathrm{KMnO}_{4}$ is shown in Fig.4.

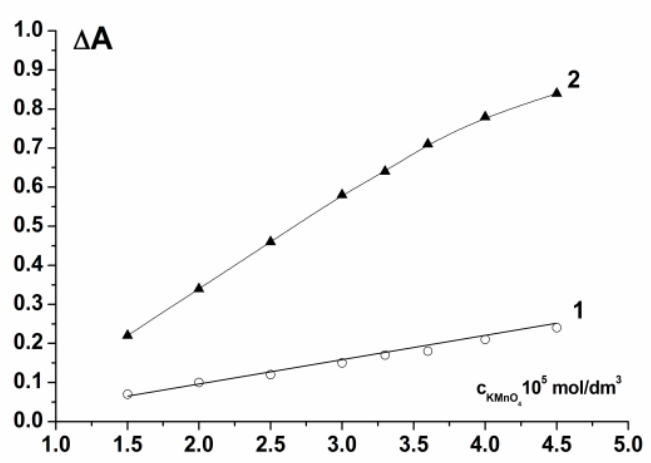

Fig. 4. Dependence of the reaction rate on $\mathrm{KMnO}_{4}$ concentration. Initial conditions: $2.7510^{-5} \mathrm{~mol} / \mathrm{dm}^{3} 4-$ hidroxycoumarine; $\mathrm{pH}=1.74 ; 200 \mathrm{ng} / \mathrm{cm}^{3} \mathrm{~W}(\mathrm{VI})$; temperature $25 \pm 0.1{ }^{\circ} \mathrm{C}$; 1 -inhibited reaction; 2-noninhibited reaction.

It is obviously from Fig. 3 that the inhibited reaction is the first-order in the all range of presented concentrations, while the basic non-inhibited reaction is the first-order for the concentrations less than $3.6 \cdot 10^{-5} \mathrm{~mol} / \mathrm{dm}^{3}$. 


\subsection{Effect of tungsten (VI) concentration}

Under optimal conditions $3.6 \cdot 10^{-5} \mathrm{~mol} / \mathrm{dm}^{3}$ $\mathrm{KMnO}_{4} ; 2.7510^{-5} \mathrm{~mol} / \mathrm{dm}^{3}$ 4-hidroxycoumarine $\mathrm{pH}=$ $1.74)$, the tungsten (VI) concentration has been varied from 10 to $250 \mathrm{ng} / \mathrm{cm}^{3}$. Fig. 5 shows the calibration line which can be used for determination of $\mathrm{W}(\mathrm{VI})$ in the interval of concentration mentioned above at temperatures $20 \pm 0.1{ }^{\circ} \mathrm{C}(1)$ and $25 \pm 0.1{ }^{\circ} \mathrm{C}$ (2).

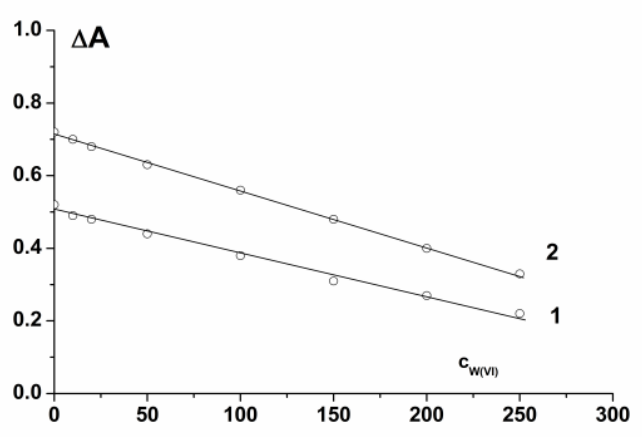

Fig. 5. Dependence of the reaction rate on $\mathrm{W}(\mathrm{VI})$ concentration. Initial conditions: $3.6110^{-5} \mathrm{~mol} / \mathrm{dm}^{3}$ $\mathrm{KMnO}_{4} ; 2.75 \cdot 10^{-5} \mathrm{~mol} / \mathrm{dm}^{3}$ 4-hidroxycoumarine; $\mathrm{pH}=$ 1.74; 1-temperature $20 \pm 0.1{ }^{\circ} \mathrm{C}$; 2-temperature $25 \pm 0.1$ ${ }^{\circ} \mathrm{C}$.

Based on calibration line (2), at $25^{\circ} \mathrm{C}$, the unknown concentration of $\mathrm{W}(\mathrm{VI})$ can be determined by following equation:

$$
c_{W(V I)}=\frac{0.72-\Delta A}{0.00152}(=) \mathrm{ng} / \mathrm{cm}^{3}
$$

where $\Delta \mathrm{A}$ is the change of absorbance for indicator substance $\left(\mathrm{KMnO}_{4}\right)$ after $195 \mathrm{~s}$ from the beginning of the reaction.

The limits of detection (LOD) and quantitation (LOQ) were found to be 4.5 and $15.1 \mathrm{ng} / \mathrm{cm}^{3}$ and they are evaluated using the following equations:

$$
\begin{aligned}
& \mathrm{LOD}=3.3 \mathrm{~S} / \mathrm{b} \\
& \mathrm{LOQ}=10 \mathrm{~S} / \mathrm{b}
\end{aligned}
$$

where $\mathrm{S}$ is the residual standard deviation of the calibration line and $\mathrm{b}$ is the slope of the calibration line.

The relationship between the reaction rates and the concentrations of the reacting components can be explained by the following kinetic equations (at constant $\mathrm{pH}$ ):

For the inhibited reaction $\left(\mathrm{C}_{\text {coum }} \leq 410^{-5} \mathrm{~mol} / \mathrm{dm}^{3}\right.$; $\mathrm{C}_{\mathrm{MnO}^{4}} \leq 4.5 \cdot 10^{-5} \mathrm{~mol} / \mathrm{dm}^{3}$ and $\left.20 \leq \mathrm{C}_{\mathrm{W}(\mathrm{VI})} \leq 250 \mathrm{~g} / \mathrm{cm}^{3}\right)$ :

$$
-\left(\frac{d c}{d t}\right)=k \cdot c_{\text {coum }} \cdot c_{M n O_{4}^{-}} \cdot c_{W(V I)}^{-1}
$$

where $k$ is the constant which is proportional to the constant rate of inhibited reaction.

For the non-inhibited reaction $\left(\mathrm{C}_{\text {coum }} \leq 2.7510^{-5}\right.$ $\left.\mathrm{mol} / \mathrm{dm}^{3} ; \mathrm{C}_{\mathrm{MnO} 4} \leq 3.610^{-5} \mathrm{~mol} / \mathrm{dm}^{3}\right)$ :

$$
-\left(\frac{d c}{d t}\right)=k_{0} \cdot c_{\text {coum }} \cdot c_{M n O_{4}^{-}}
$$

where $k_{0}$ is the constant which is proportional to the constant rate of non-inhibited reaction.

Accuracy and precision are presented in Table 1 . The probable relative error ranges from 13 to $-4.8 \%$ for $\mathrm{W}(\mathrm{VI})$ concentration from 20 to $250 \mathrm{ng} / \mathrm{cm}^{3}$

Table 1. Accuracy and precision of tungsten $\mathrm{W}(\mathrm{VI})$ determination

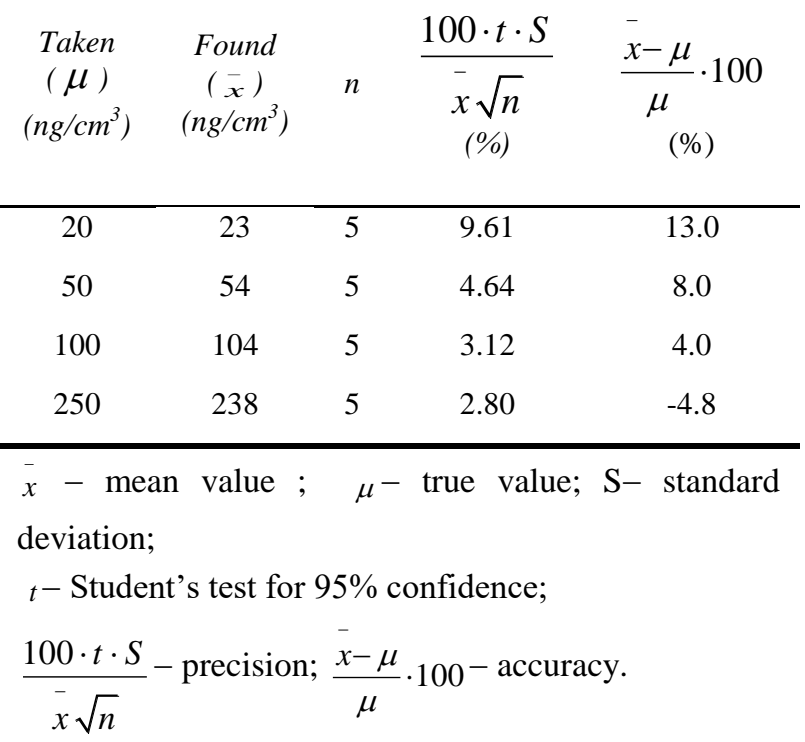

\subsection{Interference study}

To access the selectivity of the method, influences of some foreign ions on the inhibited reaction rates were studied, at the constant $\mathrm{W}(\mathrm{VI})$ concentration of $200 \mathrm{ng} / \mathrm{cm}^{3}$. The method has relative good selectivity . The results are presented in Table 2 .

\section{Chemistry}


Table 2. Influence of interfering ions for determination of $\mathrm{W}(\mathrm{VI})$ by proposed method $* \mathrm{~W}(\mathrm{VI})$ concentration of $200 \mathrm{ng} / \mathrm{cm}^{3}$.

\begin{tabular}{ccc}
\hline $\begin{array}{c}\text { Tolerance limit } \\
\text { Foreign ion/W(VI)* }\end{array}$ & Con added \\
\hline $10^{4}$ & $\mathrm{Cl}^{-}, \mathrm{Na}^{+}, \mathrm{K}^{+}, \mathrm{NH}_{4}{ }^{+}, \mathrm{Mg}^{2+}, \mathrm{Sr}^{2+}, \mathrm{Ca}^{2+}, \mathrm{Ba}^{2+}$ & does not interfere \\
400 & $\mathrm{Hg}^{2+}, \mathrm{Cd}^{2+}, \mathrm{Sn}^{2+}, \mathrm{Pb}^{2+}, \mathrm{Ni}^{2+}$ & does not interfere \\
200 & $\mathrm{Al}^{3+}, \mathrm{Co}^{2+}, \mathrm{Cu}^{2+}, \mathrm{Fe}^{3+}, \mathrm{Cr}^{3+}, \mathrm{Pd}^{2+}, \mathrm{Pt}^{4+}$ & does not interfere \\
100 & $\mathrm{Zn}^{2+}, \mathrm{Zr}^{4+}, \mathrm{Ti}^{3+}, \mathrm{AsO}_{4}{ }^{3-}, \mathrm{Sb}^{3+}, \mathrm{Bi}^{3+}$, & practically does not interfere \\
50 & $\mathrm{PO}_{4}{ }^{3-}, \mathrm{SCN}^{-}, \mathrm{C}_{2} \mathrm{O}_{4}{ }^{2-}$ and citrate & have a slightly inhibiting effect \\
40 & $\mathrm{Ag}^{+}$ & have a slightly catalytic effect \\
10 & $\mathrm{VO}^{2+}$ & inhibit the reaction \\
5 & $\mathrm{MoO}_{4}{ }^{2-}$ & inhibit the reaction \\
1 & $\mathrm{Mn}^{2+}, \mathrm{Au}^{3+}$ & catalyze the reaction
\end{tabular}

\section{CONCLUSION}

This work describes kinetic method for the determination of trace amounts of tungsten (VI), which is based on the inhibitory effect on the oxidation of 4hidroxycoumarine by $\mathrm{KMnO}_{4}$ at $\mathrm{pH}=1.74$. The optimal conditions for this kinetic spectrophotometric method are found and equation which allowed determination of unknown concentration of tungsten by measuring the absorbance after $195 \mathrm{~s}$ from the beginning of the reaction, at $525 \mathrm{~nm}$, is evaluated. The interference study suggests a relative good selectivity, indicating possibility of successful determination in complex matrix of a real sample. Statistic calculations based on obtained results for five times repeated determinations under the same conditions show good accuracy and precision.

\section{REFERENCES}

Alekseev, V.N. 1973. Kurs kachestvenogo polumikro analiza. Moscow: Khimya.

Alvarado-Gámez, A.L., Alonso-Lomillo, M.A., Domínguez-Renedo, O., \& Arcos-Martínez, M.J. 2015. A chronoamperometric screen printed carbon biosensor based on alkaline phosphatase inhibition for W(IV) determination in water, using 2-phosphoL-ascorbic acid trisodium salt as a substrate. Sensors (Basel), 15(2), pp. 2232-43. pmid:25621602.
-JIS G 1220. 1994. Iron and steel: Methods for determination of tungsten content.Tokyo: Japanese Industrial Standards Committee.

-JIS G 1258. 2000. Iron and steel: Methods for inductively coupled plasma atomic emission spectrometry (Amendment 1).Tokyo: Japanese Industrial Standards Committee.

Koutsospyros, A., Braida, W., Christodoulatos, C., Dermatas, D., \& Strigul, N. 2006. A review of tungsten: From environmental obscurity to scrutiny. J. Hazard. Mater, 136, pp. 1-19.

L'vov, N.P., Nosikov, A.N., \& Antipov, A.N. 2002. Tungsten-containing enzymes. Biochemistry Mosc., 67(2), pp. 196-200. pmid:11952415. doi:10.1023/A:1014461913945

Masti, S.P., Seetharamappa, J., \& Melwanki, M.B. 2002. Extractive Spectrophotometric Determination of Tungsten(VI) in Alloy Steels Using Ethopropazine Hydrochloride. Analytical Sciences, 18(8), doi:10.2116/analsci.18.913

Micić, R.J., Simonović, R.M., \& Petković, B.B. 2006. Kinetic Spectrophotometric Determination of Traces of Manganese(II) by Its Catalytic Effect on Oxidation of 4-Hidroxycoumarine with Potassium Permanganate in River Water Samples. Analytical Letters, 39, pp. 425-433.

Muller, H., Oto, M., \& Werner, G. 1980. Katalytishe metoden in der spurenanalyse.Leipzig: Akademische Verlagsgesellschaft Geest und Portig K. G..

Petković, B.B., Simonović, R.M., \& Micić, R.J. 2007. Determination of Ultramicroquantities of $\mathrm{Au}(\mathrm{III})$ by Its Catalytic Effect on 4-Hydroxyl Coumarone

\section{Chemistry}


Oxidation with Potassium Permanganate. J. Anal. Chem., 62, pp. 697-700.

Rohilla, J., Baweja, R.K., \& Kumar, S. 2013. Spectrophotometric determination of tungsten (VI) after extraction of its 6-chloro-3-hydroxy-2-phenyl4-oxo-4H-1-benzopyran complex into chloroform. Arch. Appl. Sci. Res., 5, pp. 81-89.

Strekopytov, S.V., \& Dubinin, A.V. 1997. Determination of $\mathrm{Zr}$, Hf, Mo, W and Th in standard reference samples of ocean sediments by inductively coupled plasma mass spectrometry. J. Anal. Chem., 52, pp. 1171-1174.

Strigul, N. 2010. Does speciation matter for tungsten ecotoxicology. Ecotoxicol. Environ. Saf, 73, pp. 1099-1113.

*E-mail: branka.petkovic@pr.ac.rs
Strigul, N., Koutsospyros, A., \& Christodoulatos, C. 2010. Tungsten speciation and toxicity: Acute toxicity of mono- and poly-tungstates to fish. Ecotoxicol. Environ. Saf., 73, pp. 164-171.

Tajima, Y. 2003. 'The effects of tugstophosphate and tungtosiloicate on various stress promoters transformation', Escherichia Coli. J. Inorg. Biochem, 94, pp. 155-160.

Tanaka, T., Sakairi, Y., \& Ishiyama, T. 2001. Determination of Tungsten in Iron and Steel by Adsorptiv Stripping Voltammetry. Anal. Sci., 17, pp. 949-952.

Zarei, K., Atabati, M., \& Shoari, R. 2010. Catalytic adsorptive stripping voltammetry determination of ultratrace amount of thungsten using factorial design for optimization. J Anal. Chem., 65, pp. 518-524.

\section{Chemistry}

